\title{
Detection of two morphologically cryptic species from the cursor complex (Akodon spp; Rodentia, Cricetidae) through the use of RAPD markers
}

\author{
G.M. Yazbeck, R.L. Brandão, H.M. Cunha and A.P. Paglia \\ Departamento de Biologia Geral, Universidade Federal de Minas Gerais, \\ Belo Horizonte, MG, Brasil \\ Corresponding author: G.M. Yazbeck \\ E-mail: dna@ufmg.br
}

Genet. Mol. Res. 10 (4): 2881-2892 (2011)

Received February 8, 2011

Accepted June 25, 2011

Published November 22, 2011

DOI http://dx.doi.org/10.4238/2011.November.22.2

\begin{abstract}
The cursor complex is a group within the Akodon genus of South American rodents, formed by Akodon cursor and A. montensis. Correct distinction between these two species is of great importance since they can harbor different Hantavirus strains. These species are only distinguishable by means of karyotypic or internal anatomic features, requiring dissection; recently, some other genetic methods have become available. We developed RAPD markers capable of distinguishing between A. cursor and A. montensis. Samples included 42 individuals of $A$. cursor from four localities and 16 individuals of A. montensis from two localities. Fifty-five bands, 41 of which were polymorphic, were analyzed. A principal component analysis showed that this set of markers could successfully distinguish between the two species, mainly based on three RAPD bands. The number of bands in each population was compared within a $95 \%$ confidence interval as a measure of intraspecific variability. The $A$. cursor populations were found to have marked genetic structure across the study area (AMOVA; $F_{\mathrm{ST}}=0.21$ ), which in part might be because of the relatively limited
\end{abstract}


dispersal capabilities of this species. Species-specific bands, with potential for species identification, were identified.

Key words: Akodon; Cryptic species; RAPD; Akodon cursor; Genetic variability; Hantavirus reservoir

\section{INTRODUCTION}

The correct species identification is of uttermost importance to the understanding and conservation of biodiversity. Many animal taxa have genera wherein species pairs or groups do not exhibit clear conspicuous morphological differentiation (see Jones and van Parijs, 1993; Baker et al., 1995; Merilä et al., 2001; Molbo et al., 2003; Hebert et al., 2004). Akodon cursor (Winge, 1887) and A. montensis (Thomas, 1913) (Rodentia, Cricetidae) are morphologically cryptic species from the southeastern portion of South America, which belong to a species group known as the cursor complex (Liascovich and Reig, 1989). Both rodent species are virtually undistinguishable by morphological features and, in practice, the species diagnosis can only be unambiguously made through karyotype analysis or other genetic means (Geise et al., 2005) such as mitochondrial DNA (mtDNA) sequence analysis or restriction fragment length polymorphism (RFLP). A. cursor is known to bear karyotypes of $2 \mathrm{~N}=14$ or 15 , and $A$. montensis shows $2 \mathrm{~N}=24,25$ or 26 . Another putative species in this group is $A$. aff. cursor, with $2 \mathrm{~N}=16$, but it has been reassigned to $A$. cursor by Nogueira and Fagundes (2008). These karyotypic polymorphisms are mainly due to complex chromosomal rearrangements, such as Robertsonian fusions/fissions, pericentric inversions and deletions (Patton and Sherwood, 1983), and it has been shown that A. cursor and A. montensis still share extensive chromosome rearrangements (Fagundes et al., 1997), possibly due to recent cladogenesis (Geise et al., 1998). Geographic distribution of both species overlaps and natural hybrids have been reported, although infertile (Yonenaga et al., 1975). Besides these plastic and variable karyotypic features, some species in the Akodon genus display other genetic idiosyncrasies such as reversion of the heterogametic sex determination mechanisms, with XY females (Hoekstra and Edwards, 2000). This genus is the most speciose among the Akondontini tribe (Geise et al., 2001).

RAPD analysis is a relatively fast and practical way to access genetic variability of organisms that have not been characterized for more specific markers such as microsatellites. Besides its application in the assessment of genetic population structure in an array of species without previous molecular characterization, RAPD has been used to distinguish among different varieties and strains in microorganisms, crops, other cultivated plants, domestic animals, as well among closely related and cryptic species in the wild (see Al-Barrak et al., 2004; Whitton et al., 2008; Premanandh et al., 2009).

The correct delimitation and identification of cryptic species is of great importance for providing biome conservation strategy guidelines as well as creating a map for the rational use of biodiversity's genetic resources. Scrutinizing among these two species from the cursor complex is also very important since both have been implicated in different Hantavirus outbreaks. This study describes RAPD markers capable of identifying two species of the cursor group (A. cursor and A. montensis), and attempts to perform a preliminary RAPD genetic diversity survey on a group of $A$. cursor populations from southeastern Brazil living in frag- 
mented environmental patches. The understanding of genetic structure in this species remains limited and it might supply information regarding population processes that act on fragmented populations, in particular when confronting the mounting environmental pressures over the Atlantic rainforest and Cerrado biomes.

\section{MATERIAL AND METHODS}

A total of six populational samples from five distinct municipalities in the State of Minas Gerais and their surrounding geographical area were obtained between the years of 1999 and 2001 totaling 58 individuals (42 A. cursor and 16 A. montensis). Table 1 shows sample size and locality of each populational sample. Animals were captured with Sherman live traps using banana pieces and ground corn as bait. Traps were arranged in transects placed inside forest fragments ("Jambreiro" and "Lavras" for A. montensis; "Corredor" for A. cursor) or in grass fields outside fragment borders ["Paraíso", Federal University of Viçosa (UFV) and Espírito Santo (ES)]. Each individual was marked (to avoid resampling by recapture), weighed and measured for total body, foot, ear, and tail lengths. A small piece $(\sim 1.5 \mathrm{~cm})$ of the tail tip was obtained and preserved in $70 \%$ ethanol until DNA extraction.

\begin{tabular}{|c|c|c|c|c|c|c|}
\hline \multirow[t]{2}{*}{ Population label } & \multirow[t]{2}{*}{ Locality } & \multirow[t]{2}{*}{$\mathrm{N}$} & \multirow[t]{2}{*}{ Species } & \multirow[t]{2}{*}{ Fragment area (ha) } & \multicolumn{2}{|c|}{ Geographic coordinates } \\
\hline & & & & & Longitude & Latitude \\
\hline UFV & Viçosa, MG & 14 & Akodon cursor & 10.7 & $42^{\circ} 52^{\prime} 55^{\prime \prime} \mathrm{W}$ & $20^{\circ} 45^{\prime} 14^{\prime \prime S}$ \\
\hline Corredor & Bocaiúva, MG & 12 & Akodon cursor & 542.3 & $43^{\circ} 53^{\prime} 34^{\prime \prime W}$ & $17^{\circ} 22^{\prime} 52^{\prime \prime S}$ \\
\hline Paraíso & Viçosa, MG & 9 & Akodon cursor & 384 & $42^{\circ} 51^{\prime} \mathrm{W}$ & $20^{\circ} 45^{\prime} \mathrm{S}$ \\
\hline ES & Venda Nova, ES & 7 & Akodon cursor & 16 & $41^{\circ} 08^{\prime} 03^{\prime \prime} \mathrm{W}$ & $20^{\circ} 20^{\prime} 23^{\prime \prime S}$ \\
\hline Jambreiro & Nova Lima, MG & 9 & Akodon montensis & 912 & $43^{\circ} 50^{\prime} 48^{\prime \prime} \mathrm{W}$ & $19^{\circ} 59^{\prime} 08^{\prime \prime} \mathrm{S}$ \\
\hline Lavras & Lavras, MG & 7 & Akodon montensis & 54.4 & $44^{\circ} 59^{\prime} 59^{\prime \prime} \mathrm{W}$ & $21^{\circ} 14^{\prime} 47^{\prime \prime S}$ \\
\hline
\end{tabular}

$\mathrm{ES}=$ Espírito Santo; UFV = Universidade Federal de Viçosa.

Animals were released at capture points, except one or more individuals from each locality, which were collected for karyotyping purposes. Karyotype species diagnoses were carried out under the auspices of Dr. Pablo Rodrigues Gonçalves (Paraíso, UFV and ES), Maria Olímpia Lopes (Corredor and Lavras), and Dr. Lena Geise (Jambreiro). Total genomic DNA was extracted with a phenol-chloroform/proteinase $\mathrm{K}(10 \mu \mathrm{g} / \mu \mathrm{L})$ protocol using the Madisen lysis buffer ( $0.1 \mathrm{M}$ Tris- $\mathrm{HCl}, 40 \mathrm{mM}$ EDTA, $0.2 \%$ SDS, $1 \mathrm{M} \mathrm{NaCl})$. PCR assays were carried out using a total volume of $16 \mu \mathrm{L}$ containing $10 \mathrm{mM}$ Tris-HCl, $\mathrm{pH} 8.0,50 \mathrm{mM}$ $\mathrm{KCl}$ and $2 \mathrm{mM} \mathrm{MgCl}$ buffer, $1 \mu \mathrm{M}$ of each dNTP, $0.25 \mu \mathrm{M}$ of a single primer, $1 \mathrm{U}$ TaqDNA-polymerase (Phoneutria, Belo Horizonte, MG, Brazil) and 1 to $5 \eta \mathrm{g}$ target DNA. PCR cycles were as follows: an initial denaturation of $1 \mathrm{~min}$ at $95^{\circ} \mathrm{C}$, then, $30 \mathrm{~s}$ at $94^{\circ} \mathrm{C}, 1 \mathrm{~min}$ at $36^{\circ} \mathrm{C}$ and 2 min at $72^{\circ} \mathrm{C}, 35$ times, followed by a 7 -min final extension step at $72^{\circ} \mathrm{C}$, using a PTC-100 (M.J. Research, Watertown, MA, USA) thermocycler. PCR assays were always accompanied by a negative control reaction, with no template DNA added. RAPD products were visualized by standard electrophoresis procedures on $1 \%$ agarose gels, stained with 1 $\eta \mathrm{g} / \mu \mathrm{L}$ ethidium bromide.

Gels were photographed on monochromatic Polaroid film and visually scored with the 
aid of two 100-bp DNA-Ladder lanes (Invitrogen Life Technologies, São Paulo, SP, Brazil). A total of 56 decamer arbitrary primers (20 from the OP-A set, 20 from the OP-B set, 8 from the OP-C set, and 8 from the OP-L set) (Operon Technologies, Alameda, CA, USA) were tested for polymorphisms in a set of eight randomly selected individuals from two different populations. We screened for primers yielding clear distinguishable and highly recurrent patterns in independent repeat amplification assays. The selected primers for this study were OP-A2, OPA4, OP-A7, OP-C16, and OP-L1.

RAPD bands were scored and assigned 0 or 1 values for absence or presence (RAPD phenotypes). The resulting dataset was analyzed for the number of polymorphic bands, comparing samples by means of a $95 \%$ confidence interval obtained from a jackknife polymorphic band richness estimator as a within-population diversity measure. With the Arlequin software we calculated the pairwise $F_{\mathrm{ST}}$ values (Weir and Cockerham, 1984) among samples of $A$. cursor populations and assessed a two-level analysis of molecular variance (AMOVA) (Excoffier et al., 1992) for this species, over RAPD phenotypes, assuming the same mating patterns within each population. We performed a principal component analysis (PCA) over polymorphic RAPD bands using a correlation matrix. The four biometric features measured were compared by means of analysis of variance (ANOVA) among each population sample from both species pulled together. The Mantel test was performed using geographic distances among localities $(\mathrm{km})$ and genetic distance (pairwise $F_{\mathrm{ST}}$ ), with the Mantel Nonparametric Test Calculator 2.0 for the A. cursor population samples. A phenogram was constructed by unweighted pair group method with arithmetic mean (UPGMA) with Nei's genetic distance (1972), and allelic frequencies being calculated by assuming Hardy-Weinberg equilibrium, according to the method presented by Lynch and Milligan (1994), with the aid of the Tools for Population Genetic Analyses software.

\section{RESULTS}

RAPD-PCR assays revealed a total of 55 recurrent scorable bands throughout the five primer set tested, 41 being polymorphic bands. Table 2 shows these primers and their respective number of yielded bands. RAPD bands were named after the primer used, followed by their approximate size in base pairs. Each individual within the whole sample set exhibited a unique RAPD banding profile.

Table 2. Arbitrary primers used, number and amplicon size range of RAPD bands.

\begin{tabular}{llcc}
\hline Primer & Sequence $\left(5^{\prime}-3^{\prime}\right)$ & Number of bands (polymorphic/monomorphic) & Approximate fragment size range (bp) \\
\hline OPA-2 & TGCCGAGCTG & $9(4 / 5)$ & $600-1700$ \\
OPA-4 & AATCGGGCTG & $4(2 / 2)$ & $420-1200$ \\
OPA-7 & GAAACGGGTG & $14(13 / 1)$ & $600-1600$ \\
OPC-16 & CACACTCCAG & $14(13 / 1)$ & $500-2050$ \\
OPL-1 & GGCATGACCT & $14(9 / 5)$ & $390-1400$ \\
All & & $55(41 / 14)$ & $390-2050$ \\
\hline
\end{tabular}

From the 41 polymorphic bands found in both species, only two bands were speciesspecific (C16-700 and L1-450), both present in all A. cursor individuals and completely absent 
in A. montensis. The band C16-850 was absent in A. cursor and present in all but one A. montesis individual. These bands can be visualized in Figure 1. Two different polymorphic bands had a prevalent frequency in A. cursor and were consistently absent in A. montensis (A4-1170, present in only one A. montensis individual, and C16-2000) and two other were completely missing in A. cursor but prevalent in A. montensis (A7-690 and C16-550). Both species shared 34 other polymorphic bands in common.

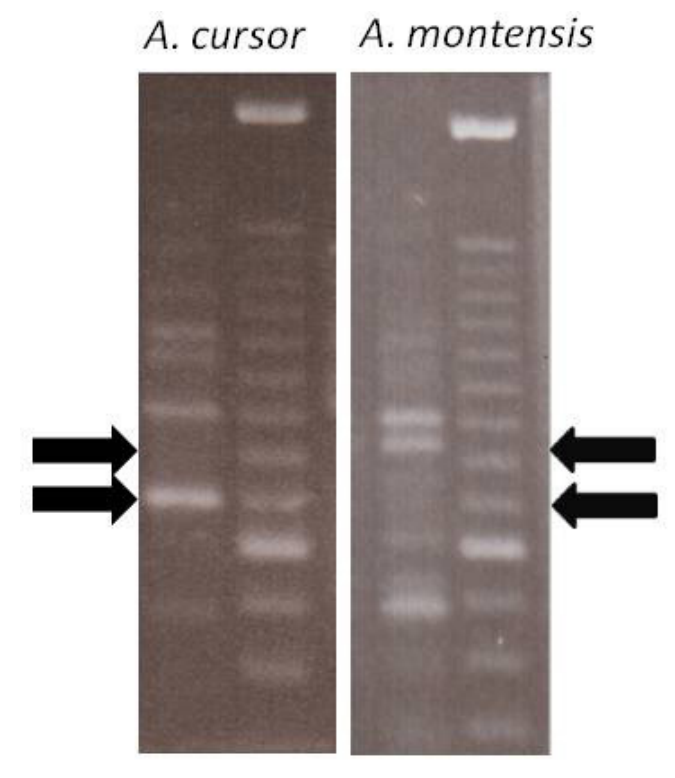

A

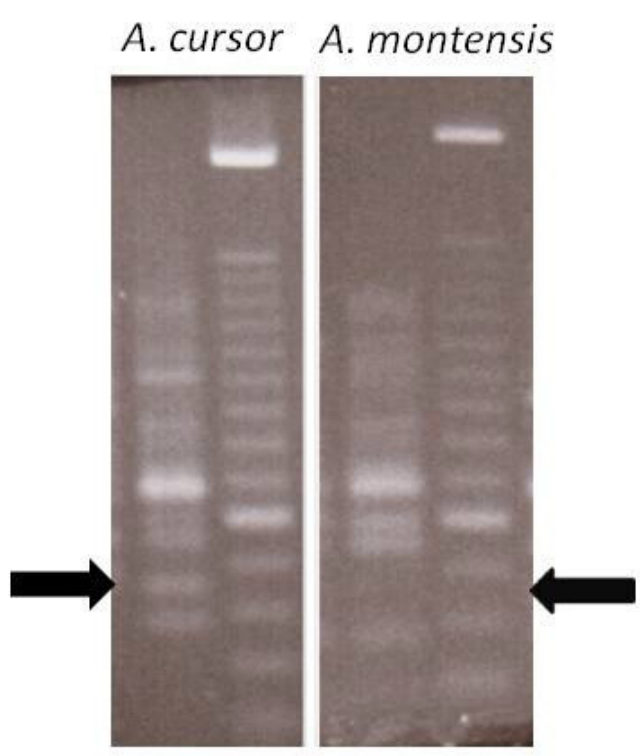

B

Figure 1. Species-specific RAPD markers. Each pair of lanes represents an individual amplification profile (left) and a reference standard DNA ladder with 100-bp increments (right); the lower stronger band being the 600-bp position. A. Bands generated with the OP-C16 primer, evidencing the region of the C16-700 band (lower arrows) exclusive of Akodon cursor and the region of the C16-850 band (upper arrows), exclusive of $A$. montensis. B. Bands generated with the OP-L1 primer, evidencing the region of the L1-450 band (arrows), exclusive of $A$. cursor.

An exploratory PCA was performed over the 41 RAPD bands polymorphic within or between species and the result is presented in Figure 2. Each factor is an association of variables (polymorphic bands) that best encompasses the variation found in the whole data set. The two species were clearly separated by the first factor (factor 1). Factor loading of each band for the factors 1 and 2 allowed the identification of which bands accounted for most of the variation that best discriminates among species and population samples (factor loadings $>|0.7|)$. Bands that showed marked differences in frequency between species were the ones with the highest associated factor loadings (absolute values) and those were the markers that best explained the variation between species. The two A. montensis populations (Lavras and Jambreiro) were further distinguished from each other in relation to factor 2, for which the bands A7-600, A7-920 and A7-1400 accounted for the most part of this variation. These results point to the species-specific nature of some markers generated herein. 


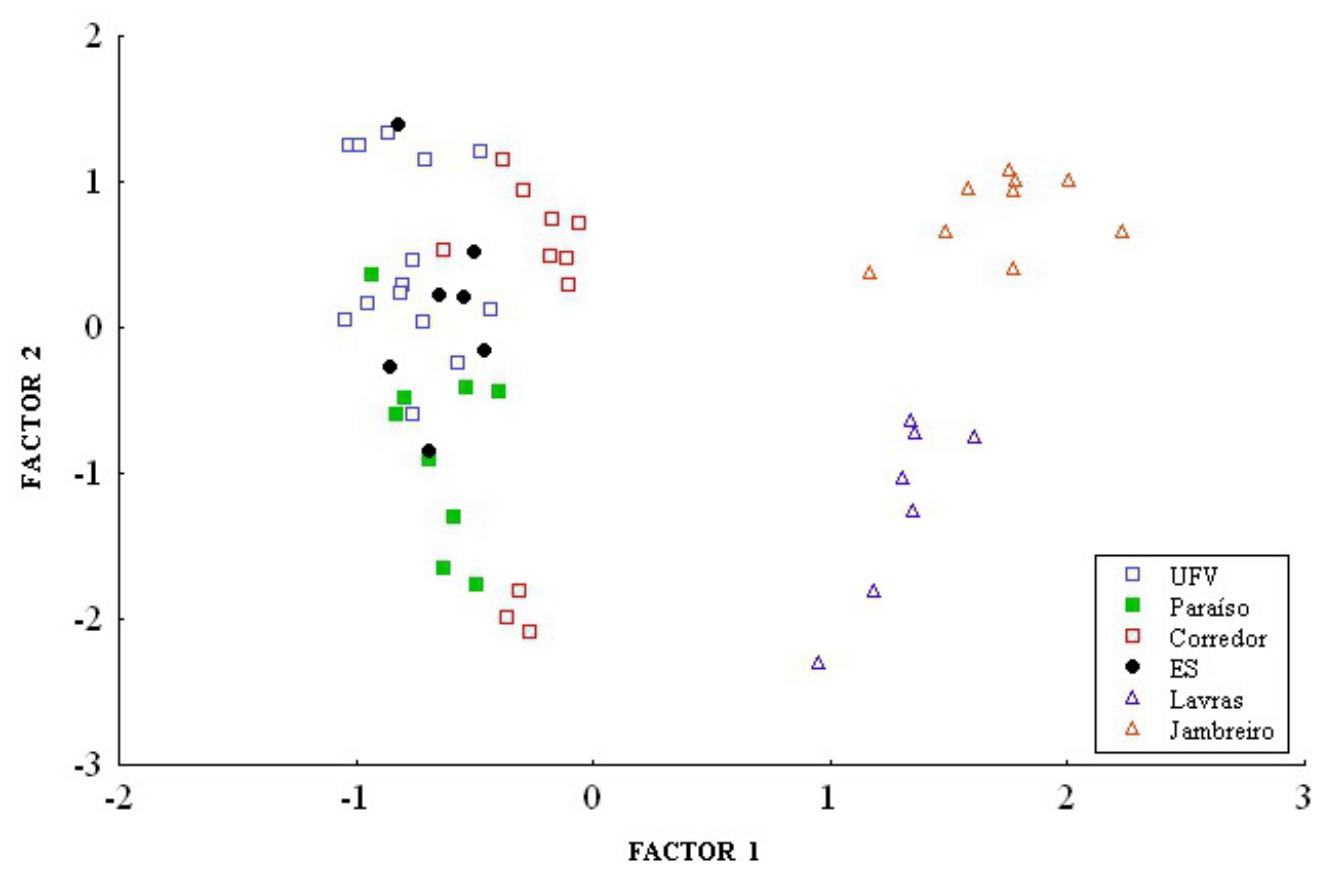

Figure 2. Principal component analysis graphic evidencing the separation of populations from both species, Akodon cursor (UFV, Corredor, Paraíso, and ES) and A. montensis (Jambreiro and Lavras). UFV = Universidade Federal de Viçosa; ES = Espírito Santo.

\section{Akodon cursor genetic variability}

With the aim of assessing the presence of populational genetic structure among the four A. cursor populations (UFV, Corredor, Paraíso, and ES), we performed a two-level AMOVA over RAPD phenotypes (i.e., without pooling populations into groups). The amount of variability distributed among populations was $20.8 \%$. The remaining $79.2 \%$ was due to individual differences within populations. The former value can be considered high and indicates the presence of a marked genetic structure in this species, across the study's range.

Pairwise $F_{\mathrm{ST}}$ comparisons among populations (Table 3) showed that the lowest differentiation was found between the UVF and ES pair, even though they are not the closest geographically situated pair $\left(F_{\mathrm{ST}}=0.116\right)$ and the highest differentiation was found among the Corredor and UFV populations $\left(F_{\mathrm{ST}}=0.247\right)$. All $F_{\mathrm{ST}}$ values presented in Table 3 were highly significant $(\mathrm{P}<0.001)$. This indicates the presence of marked genetic differentiation in each pair of $A$. cursor populations studied.

Intrapopulational genetic diversity was evaluated through 95\% confidence intervals from a jackknife richness estimator, considering the number of bands found within each population. Only the ES population showed superior number of bands ( 38) compared to the other populations $(\sim 33)$. All the remaining populations showed no statistical difference in the number of RAPD bands among them (data not shown).

Geographic distances did not correlate with genetic distances $\left(F_{\mathrm{ST}}\right)$, according to the 
Mantel test $(\mathrm{P}>0.05, \mathrm{z}=773.7)$. The resulting UPGMA phenogram constructed with Nei's genetic distance (Figure 3) grouped each species within a clade, confirming the PCA, but the relationship of populations within the $A$. cursor clade was slightly different from that found with pairwise $F_{\text {ST }}$ divergence analysis.

Table 3. Pairwise $F_{\mathrm{ST}}$ (lower half) and geographic distances (in km, upper half) among Akodon cursor populations.

\begin{tabular}{lcccc}
\hline & UFV & Corredor & Paraíso & ES \\
\hline UFV & - & 417 & 15 & 187 \\
Corredor & 0.247 & - & 475 & 456 \\
Paraíso & 0.149 & 0.240 & - & 201 \\
ES & 0.116 & 0.240 & 0.228 & - \\
\hline
\end{tabular}

$\mathrm{ES}=$ Espírito Santo; UFV = Universidade Federal de Viçosa.

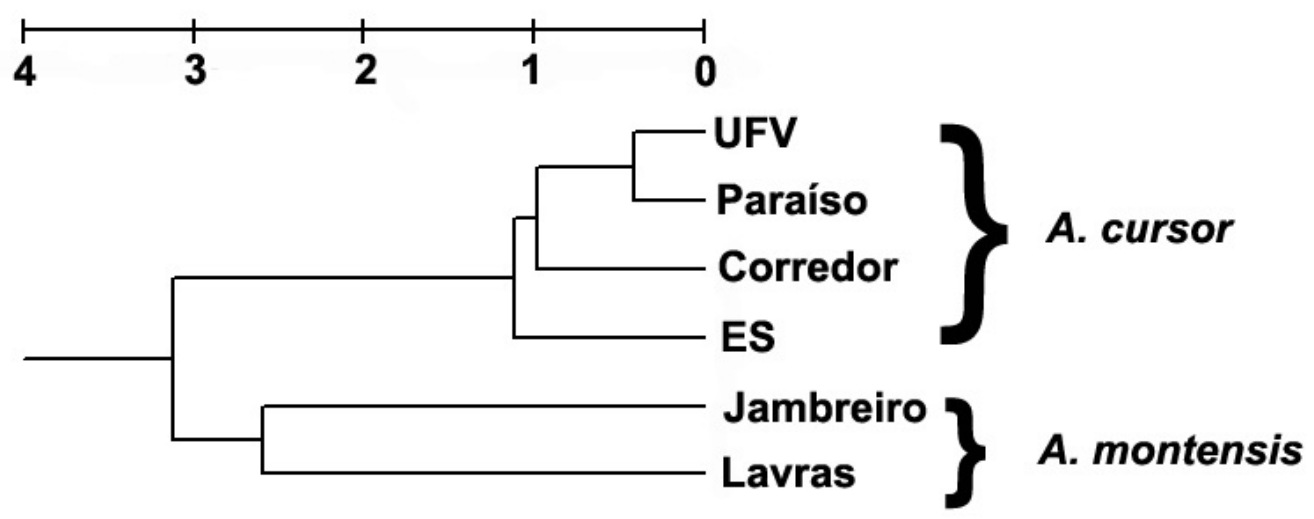

Figure 3. UPGMA tree constructed over Nei's genetic distance. For abbreviations, see Figure 2.

None of the morphological features assessed showed statistically significant differentiation in ANOVA, except for ear length $(\mathrm{F}=3.8$, d.f. $=5$ and $\mathrm{P}=0.006)$ with the $A$. montensis population of Lavras showing slightly larger average ear length. Total body, foot and tail lengths did not show similar trends $(\mathrm{F}=2.3$, d.f. $=5$ and $\mathrm{P}=0.06 ; \mathrm{F}=2.1$, d.f. $=5$ and $\mathrm{P}=0.08$ and $\mathrm{F}=0.33$, d.f. $=5$ and $\mathrm{P}=0.88$, respectively). No sexual dimorphism was found for any of the characters evaluated (data not show).

\section{DISCUSSION}

The 41 polymorphic RAPD bands used in this study could correctly distinguish among populations from two cryptic species of the cursor complex, assigning samples into two species, A. cursor or A. monstensis. According to Geise et al. (2005), A. montensis is typically found in altitudes superior to $800 \mathrm{~m}$ above sea level and $A$. cursor is found in altitudes that vary from sea level to above $1000 \mathrm{~m}$, although they have been reported to be found in sympatry (Fagundes and Nogueira, 2007). Identification of both species is normally made through karyotype, skull and molar analysis. Also, Geise et al. (2004) reported that A. mon- 
tensis lacks the gall bladder. Because these characteristics are only intrusively accessed and, in some cases, depend on systematic specialists, the RAPD diagnosis of the A. cursor or $A$. montensis species could also provide an alternative non-intrusive identification method. The source for DNA testing could be from either a dead or living specimen, although detection via droppings is not recommended a priori due to potential unspecific amplification using arbitrary primers. For this purpose longer, more specific primers embedding the useful decamers determined here would be suitable and can be achieved through isolation, cloning and characterization of these RAPD bands.

From all 41 bands used in the PCA, only two showed to be species-specific (C16700 and L1-450) and exclusive of A. cursor. Therefore, the method for positive A. cursor identification relies on the detection of one or both bands in electrophoretic assays. Positively controlled RAPD-PCR assays using these primers in a cursor group individual, along with the detection of the absence of both markers, are indicative of $A$. montensis identification. These two markers have the potential for being targeted for complete characterization by molecular cloning and sequencing so more specific primers could be designed and tested as novel $A$. cursor-specific markers (sequence-characterized amplified region). Furthermore, these bands could be targeted for the design of species-specific tagged molecular probes to be used in Southern blotting or fluorescent in situ hibridization, so molecular, karyotypic and genomic position mapping studies could be integrated. Also, the C16-850 band was present in all but one A. montesis and completely absent in A. cursor. It is possible that this band also consists in a species-specific marker for $A$. montensis and that its absence from only one individual was due to PCR amplification allelic dropout or another technical artifact and larger A. montensis samples should be verified to corroborate this possibility. Therefore, absence of both A. cursor-specific bands (C16-700 and L1-450) allied to the detection of the C16-850 marker should be regarded as a positive $A$. montensis identification for cursor complex specimens.

Other four bands showed to be virtually missing in one species and highly common in the other: C16-2000 and A4-1170 present only in A. cursor, and A7-690 and C16-550 present only in $A$. montensis. The sharing of 34 common polymorphic bands by both species is regarded as indicative of the fact that both species also share extensive chromosomic regions due to recent common ancestry (Geise et al., 1998). The UPGMA tree also confirmed the deep separation of both species groups.

Research on cryptic species has increased exponentially during the last decades, because of the increasing use of DNA data over several groups. The misidentification of species of medical importance can have important impacts (Bickford et al., 2007), for example in disease management. A. montensis and A. cursor have been implicated as pathological Hantavirus strain reservoir species (see Lemos et al., 2004; Sousa et al., 2008) and different types of Hantavirus can be exclusively associated with only one among closely related species (Jackson and Charleston, 2004). Hantavirus are RNA viruses linked to Hantavirus cardiopulmonary syndrome in several Brazilian regions (as well as all around the globe).

The application of the RAPD markers described here to distinguish between two species of the cursor complex is a relatively simple and straightforward process to correctly assign between those two cursor complex species. Karyotype identification generally must rely on the availability of living specimens that need to be sacrificed during protocol procedures in order to assess karyological data. Furthermore, the verification of the presence/absence of the gall bladder also requires the specimens to be sacrificed in order for the correct identification 
between A. cursor and A. montensis. Manipulation of blood and internal organs from potential zoonotic hosts, such as rodents, might pose a high biohazard to humans (Korva et al., 2009). Thus, identification by means of RAPD method is preferential because it does not implicate the need for living animals to be removed from the field, sacrificed and manipulated for identification. Also, it is more straightforward and less expensive than genetic typing by means of restriction endonuclease enzymatic DNA digestion for generating RFLP profiles as proposed by Fagundes and Nogueira (2007).

This identification tool proposed here also might be useful to re-evaluate the classification of voucher specimens where the original classification could not rely on genetic methodologies. The size of specific markers $(<1000 \mathrm{bp})$ indicates that some degree of success might be achievable for PCR amplifications of historic samples (e.g., museum specimens), even though there is a tendency for DNA to fragment into shorter segments than needed for the correct elongation of newly synthesized double-strands. Scatena and Morielle-Versute (2008) attempted to amplify different lengths of mtDNA regions from formalin-fixed archival specimens (an aggressive agent for DNA preservation), from the South American bats of the Artibeus genus, and achieved the amplification success rates ranging from 30 to $72 \%$ (in fragments of 1500 to $460 \mathrm{bp}$, respectively). However, the unspecific nature of the markers described herein might limit this application until further characterization is performed.

The relevance of the correct species identification is critical in the small muroid mammals because it is the single most diverse family of mammals and its species richness raises the question of why this group exhibits a more prominent radiation than comparable mammal groups (Steppan et al., 2004).

\section{Akodon cursor genetic population structure}

The jackknife polymorphic band richness analysis for intrapopulational genetic variability showed the ES population as having a superior number of polymorphic bands than the remaining populations. This can be understood because the ES population, collected in Venda Nova, State of Espírito Santo, has a higher variability within population. Our finding is in agreement with those of Nogueira and Fagundes (2008) who also found, in the State of Espírito Santo, A. cursor samples with higher intraspecific variability. They attributed this finding to the more central location the State has along A. cursor's geographic range (Nogueira and Fagundes, 2008).

The $F_{\mathrm{ST}}$ analysis performed here over RAPD phenotypes showed a sharp genetic structure in the $A$. cursor populations with almost $21 \%$ of the overall variation being allocated among populations. Colombi et al. (2010) also observed a marked genetic structure in A. cursor populations using an mtDNA marker. A comparatively higher proportion of the total genetic variability being allocated within populations (than among populations) is a common feature of small mammal genetic population structure (see Landry and Lapointe, 1999; Cooper, 2000; Antolin et al., 2001). Terrestrial small mammal population genetic structuring is notably more conspicuous than with flying mammals (see Ditchfield, 2000), mainly due to dispersion capabilities influencing the number of migrants among populations and its homogenizing effects against the differentiating forces of random genetic drift (isolation by distance effect). Even though there is limited value in comparing genetic divergence estimates among different RAPD genetic diversity assessments (e.g., among different species), values found here can 
be regarded as high. This can be partially understood as a reflection of the average pairwise geographic distance among forest patches from where populations were sampled ( 291 km; $\mathrm{SD}=185.5 \mathrm{~km})$. Also, A. cursor has been shown to display a relatively limited dispersion ability among fragment patches segregated by inhospitable environmental matrixes (Pires et al., 2002), even though it is seen as rather tolerant to the external habitat matrix (Figueiredo and Fernandez, 2004) and that Colombi et al. (2010) could not attribute to an important river a role of effective dispersion barrier shaping the distribution of $A$. cursor variability. The Brazilian southeast region has been intensively exploited for its forest resources, pastures and human settlement and has suffered extensive habitat degradation and fragmentation. This sharp genetic population differentiation is directly in contrast with the known prevailing lack of morphological differentiation, also confirmed here by ANOVA, within and between species for most evaluated features.

Although two of the forest patches were separated by only $15 \mathrm{~km}$ (UFV and Paraíso) they still exhibited a significant pairwise $F_{\mathrm{ST}}$ value, slightly higher than for the ES and UFV pair ( 0.15 for the former and 0.11 for the later). This might reflect a limited A. cursor dispersion capacity. Even though it is plausible to assume indirect current gene flow, as in a stepping stone model (i.e., migration through successive forest patches), between the UFV and the Paraíso populations, it is not reasonable to assume that the greater genetic similarity between the UFV and the ES populations pointed by pairwise $F_{\text {ST }}$ analysis is due to indirect current gene flow. Other possible homogenizing microevolutive force could be natural selection, although virtually no information on putative convergent selective pressures common to the studied populations is available. Those findings should be confirmed with other classes of molecular and/or enzymatic markers before more informed assumptions can be made. Another hypothetical scenario would be a relatively continuous and genetically homogeneous distribution of $A$. cursor in the studied area prior to the intense fragmentation process (mostly during the 20th century) and the subsequent differential genetic divergence among fragments due to several varying factors such as relative isolation, differential effective population size, environmental stochasticities, and newly determined selective pressures (e.g., increased border effect). A. cursor is regarded as relatively tolerant to border effect (Figueiredo and Fernandez, 2004) and could be rapidly responding to such a changing landscape. These apparent inconsistencies between genetic divergence and geographical distance, as well as lack of correlation indicated by the Mantel test could be explained by the possible recent population expansion scenario proposed by Geise et al. (2001) in A. cursor, which could disturb the expected gene flow-random genetic drift equilibrium that would lead to Wright's isolation by distance effects. Nevertheless, the UPGMA phenogram showed a more consistent phylogenetic relationship among $A$. cursor populations, as expected by relative distance among population pairs.

The lack of morphological differentiation among such a genetically variable group should be further investigated in the light of recently proposed idea that challenges the traditional interpretation of the role of the intraspecific genetic variability and its importance on the success of extant species (Makarieva AM and Gorshkov GV, unpublished results).

The basic knowledge of this species biology and the capacity to correctly identify it are of great importance for public health concerns, because of its link with Hantavirus outbreaks, and relevance in biology in general, because it constitutes a single-evolution model in mammals with the species boundaries, which still continue to be defined. 


\section{ACKNOWLEDGMENTS}

The authors would like to thank Dr. Maria Bernadete Lovato for invaluable discussions and guidance throughout the study, Dr. Maria Dolores P. Acedo for laboratory assistance, Dr. Pablo Rodrigues Gonçalves for providing samples and karyotypes, Dr. Lena Geise, Maria Olímpia Lopes, MSc, for karyotypic confirmations, Dr. Andre Hirsch, Dr. Fabrício R. Santos and Dr. Paulo De Marco Jr. Research supported by Coordenadoria de Aperfeiçoamento de Pessoal de Ensino Superior (CAPES), Conselho Nacional de Desenvolvimento Científico e Tecnológico (CNPq) and Programa de Pós-Graduação em Genética, Universidade Federal de Minas Gerais.

\section{REFERENCES}

Al-Barrak M, Loxdale HD, Brookes CP, Dawah HA, et al. (2004). Molecular evidence using enzyme and RAPD markers for sympatric evolution in British species of Tetramesa (Hymenoptera: Eurytomidae). Biol. J. Linn. Soc. Lond. 83: 509-525.

Antolin MF, Van Horne B, Berger MD Jr, Holloway AK, et al. (2001). Effective population size and the genetic structure of a piute ground squirrel (Spermophilus mollis) population. Can. J. Zool. 79: 26-34.

Baker AJ, Daugherty CH, Colbourne R and McLennan JL (1995). Flightless brown kiwis of New Zealand possess extremely subdivided population structure and cryptic species like small mammals. Proc. Natl. Acad. Sci U. S. A. 92: 8254-8258.

Bickford D, Lohman DJ, Sodhi NS, Ng PK, et al. (2007). Cryptic species as a window on diversity and conservation. Trends Ecol. Evol. 22: 148-155.

Colombi VH, Lopes SR and Fagundes V (2010). Testing the Rio Doce as a riverine barrier in shaping the Atlantic rainforest population divergence in the rodent Akodon cursor. Genet. Mol. Biol. 33: 785-789.

Cooper ML (2000). Random amplified polymorphic DNA analysis of southern brown bandicoot (Isoodon obesulus) populations in Western Australia reveals genetic differentiation related to environmental variables. Mol. Ecol. 9: 469-479.

Ditchfield AD (2000). The comparative phylogeography of neotropical mammals: patterns of intraspecific mitochondrial DNA variation among bats contrasted to nonvolant small mammals. Mol. Ecol. 9: 1307-1318.

Excoffier L, Smouse PE and Quattro JM (1992). Analysis of molecular variance inferred from metric distances among DNA haplotypes: application to human mitochondrial DNA restriction data. Genetics 131: 479-491.

Fagundes V and Nogueira CDA (2007). The use of PCR-RFLP as an identification tool for three closely related species of rodents of the genus Akodon (Sigmodontinae, Akodontini). Genet. Mol. Biol. 30: 698-701.

Fagundes V, Scalzi-Martin JM, Sims K, Hozier J, et al. (1997). ZOO-FISH of a microdissection DNA library and G-banding patterns reveal the homeology between the Brazilian rodents Akodon cursor and A. montensis. Cytogenet. Cell Genet. 78: 224-228.

Figueiredo MSL and Fernandez FAS (2004). Contrasting effects of fire on populations of two small rodent species in fragments of Atlantic Forest in Brazil. J. Trop. Ecol. 20: 225-228.

Geise L, Canavez FC and Seuanez HN (1998). Comparative karyology in Akodon (Rodentia, Sigmodontinae) from Southeastern Brazil. J. Hered. 89: 158-163.

Geise L, Smith MF and Patton JL (2001). Diversification in the genus Akodon (Rodentia: Sigmodontinae) in southeastern South America: mitochondrial DNA sequence analysis. J. Mammal. 82: 92-101.

Geise L, Weksler M and Bonvicino CR (2004). Presence or absence of gall bladder in some Akodontini rodents (Muridae, Sigmodontinae). Mamm. Biol. 69: 210-214.

Geise L, De Moraes DA and Da Silva HS (2005). Morphometric differentiation and distributional notes of three species of Akodon (Muridae, Sigmodontinae, Akondontini) in the Atlantic coastal area of Brazil. Arq. Mus. Nac. 63: 63-74.

Hebert PD, Penton EH, Burns JM, Janzen DH, et al. (2004). Ten species in one: DNA barcoding reveals cryptic species in the neotropical skipper butterfly Astraptes fulgerator. Proc. Natl. Acad. Sci U. S. A. 101: 14812-14817.

Hoekstra HE and Edwards SV (2000). Multiple origins of XY female mice (genus Akodon): phylogenetic and chromosomal evidence. Proc. Biol. Sci. 267: 1825-1831.

Jackson AP and Charleston MA (2004). A cophylogenetic perspective of rna-virus evolution. Mol. Biol. Evol. 21: 45-57.

Genetics and Molecular Research 10 (4): 2881-2892 (2011)

CFUNPEC-RP www.funpecrp.com.br 
Jones G and van Parijs SM (1993). Bimodal echolocation in pipistrelle bats: are cryptic species present? Proc. Biol. Sci. 251: 119-125.

Korva M, Duh D, Saksida A, Trilar T, et al. (2009). The hantaviral load in tissues of naturally infected rodents. Microbes Infect. 11: 344-351.

Landry PA and Lapointe FJ (1999). The genetic heterogeneity of deer mouse populations (Peromyscus maniculatus) in an insular landscape. Res. Popul. Ecol. 41: 263-268.

Lemos ERS, D’Andrea PS, Bonvicino CR, Famadas KM, et al. (2004). Evidence of Hantavirus infection in wild rodents captured in a rural area of the state of São Paulo, Brazil. Pesq. Vet. Bras. 24: 71-73.

Liascovich RC and Reig OA (1989). Low chromosomal number in Akodon cursor montensis Thomas, and karyologic confirmation of Akodon serrensis Thomas in Misiones, Argentina. J. Mammal. 70: 391-395.

Lynch M and Milligan BG (1994). Analysis of population genetic structure with RAPD markers. Mol. Ecol. 3: 91-99.

Merilä J, Kruuk LEB and Sheldon BC (2001). Cryptic evolution in a wild bird population. Nature 412: 76-79.

Molbo D, Machado CA, Sevenster JG, Keller L, et al. (2003). Cryptic species of fig-pollinating wasps: implications for the evolution of the fig-wasp mutualism, sex allocation, and precision of adaptation. Proc. Natl. Acad. Sci U. S. A. 100: $5867-5872$.

Nei M (1972). Genetic distance between populations. Am. Nat. 106: 283-292.

Nogueira CDA and Fagundes V (2008). Akodon cursor Winge, 1887 (Rodentia: Sigmodontinae): one or two species? New evidences based on molecular data. Zootaxa 1768: 41-51.

Patton JL and Sherwood SW (1983). Chromosome evolution and speciation in Rodents. Annu. Rev. Eco. Syst. 14: 139-158.

Pires AS, Lira PK, Fernandez FAS, Schittini GM, et al. (2002). Frequency of movements of small mammals among Atlantic Coastal Forest fragment in Brazil. Biol. Conserv. 108: 229-237.

Premanandh J, Priya B, Prabaharan D and Uma L (2009). Genetic heterogeneity of the marine cyanobacterium Leptolyngbya valderiana (Pseudanabaenaceae) evidenced by RAPD molecular markers and 16S rDNA sequence data. J. Plankton Res. 31: 1141-1150.

Scatena MP and Morielle-Versute E (2008). Suitability of DNA extracted from archival specimens of fruit-eating bats of the genus Artibeus (Chiroptera, Phyllostomidae) for polymerase chain reaction and sequencing analysis. Genet. Mol. Biol. 31: 160-165.

Sousa RLM, Moreli ML, Borges AA, Campos GM, et al. (2008). Natural host relationships and genetic diversity of rodentassociated hantaviruses in southeastern Brazil. Intervirology 51: 299-310.

Steppan S, Adkins R and Anderson J (2004). Phylogeny and divergence-date estimates of rapid radiations in muroid rodents based on multiple nuclear genes. Syst. Biol. 53: 533-553.

Thomas O (1913). New forms of Akodon and Phyllotis, and a new genus for "Akodon" teguina. Ann. Mag. Nat. Hist. 8: 404-409.

Weir BS and Cockerham CC (1984). Estimating F-statistics for the analysis of population structure. Evolution 38: 13581370.

Whitton J, Dlugosch KM and Sears CJ (2008). Molecular and morphological evidence for and against gene flow in sympatric apomicts of the North American Crepis agamic complex (Asteraceae). Botany 86: 877-885.

Winge H (1887). Jordfundne og nulevende gnavere (Rodentia) fra Lagoa Santa, Minas Gerais, Brasilien. E. Museo Lundii. I Art 3: 1-178.

Yonenaga Y, Kasahara S, Almeida EJ and Peracchi AL (1975). Chromosomal banding patterns in Akodon arviculoides ( $2 \mathrm{n}=14)$,Akodon sp. $(2 \mathrm{n}=24$ and 25$)$, and two male hybrids with 19 chromosomes. Cytogenet. Cell Genet. 15: 388399. 